\title{
PERLINDUNGAN ANAK KORBAN KEKERASAN \\ PERSPEKTIF HUKUM KELUARGA ISLAM (Studi Masyarakat Kubung Kabupaten Solok)
}

\author{
${ }^{1}$ Almaturidi, ${ }^{2}$ Nofialdi, ${ }^{3}$ Marhen \\ KUA Kecamatan Kubung, Kabupaten Solok, IAIN Batusangkar \\ e-mail: almaturidi.fajri@yahoo.com ,nofialdi@iainbatusangkar.ac.id, \\ marhen@iainbatusangkar.ac.id
}

\begin{abstract}
The rights of child victims of violence in the Kubung community of Solok Regency have not received their rights maximally, such as protection, education and a living. This is caused by several factors, namely the condition of the parents, knowledge, children and the family economy. The impact of violence against children has a more negative impact both in terms of physical development and from aspects of mental or physical development of children. negative effects on the mental development of children in the next life. The impact: trauma, fighting, leaving home, fear, psychological disturbance, pain. According to the perspective of Islamic Family Law as applicable in Indonesian positive law in KHI Article 105 Paragraph (3), namely being a person who is responsible for the child's economy to fulfill their needs This statement in KHI is also strengthened in positive law in Indonesia in Article 41 paragraph (1) and (2) Law no. 1 of 1974 concerning Marriage states that the father and mother are still obliged to care for and educate their children. In this case, it is very clear that what is mandated in the KHI and the Marriage Law here is that maintaining and educating children is the obligation of both parents to fulfill it. Law No. 1 of 1974 concerning Marriage and the Compilation of Islamic Law, there is no conflict regarding children's rights, they both reinforce each other
\end{abstract}

Keywords: Perlindungan, Anak, Korban, KDRT

\section{PENDAHULUAN}

Dewasa ini pemberitaan media mengenai kekerasan terhadap anak sangat memprihatinkan dan menjadi potret buram di negara Indonesia. Berdasarkan data tahun 2017, kasus kekerasan utamanya kekerasan seksual meningkat pesat. Dari sekitar 30-an kasus tahun 2016, baru pada pertengahan 2017 sudah meningkat menjadi 535 kasus. Jumlah kekerasan itu menurut Aris Merdeka Sirait meningkat pesat sejak 2014 yang tercatat ada $42 \%$ dari 426 kasus kekerasan pada anak adalah kekerasan seksual. Pada 2015 ada 50\% dari 295 kasus kekerasan pada anak adalah kekerasan seksual, dan 2016 ada 62\% dari 47 kasus kekerasan pada anak adalah kekerasan seksual.13 Menurut data Komnas Perlindungan Anak 
Indonesia (KPAI) dari Januari- Juni 2017 tercatat ada 1032 kasus kekerasan pada anak yang terdiri dari: kekerasan fisik 294 kasus (28\%), kekerasan psikis 203 kasus (20\%), dan kekerasan seksual 535 kasus (52\%). Tempat kejadian kekerasan pada anak dilingkungan sosial 385 kasus (54\%), di lingkungan keluarga 193 kasus (27\%) dan di lingkungan sekolah 121 kasus (17\%) (www.kpai.com).

Banyaknya kasus kekerasan yang terjadi di Indonesia dianggap sebagai salah satu indikator buruknya kualitas perlindungan anak. Keberadaan anak yang belum mampu untuk hidup mandiri tentunya sangat membutuhkan orang-orang sebagai tempat berlindung (Dikdik. M. Arief Mansur dan Elisatris Gultom, 2007: 122). Berdasarkan Undang-Undang No. 35 Tahun 2014 tentang perlindungan anak, yang berkewajiban dan bertanggung jawab terhadap penyelenggaraan perlindungan anak adalah negara, pemerintah, masyarakat, keluarga dan orang tua.

Telah banyak upaya dan solusi yang ditawarkan baik oleh pemerintah, lembaga perlindungan anak, ataupun para pakar perlindungan anak, akan tetapi pada realitanya masih banyak terjadi kekerasan terhadap anak di lingkungan masyarakat. Pada dasarnya upaya dan solusi tersebut tidak sepenuhnya berprinsip pada hukum keluarga Islam, meskipun teori-teori yang ditawarkan pada perlindungan anak tersebut secara tersirat prinsipnya sama dengan nilainilai yang terkandung dalam hukum keluarga Islam.

Dengan adanya ketentuan khusus yang berkaitan dengan seorang anak, baik yang diatur dalam hukum keluarga Islam maupun Perundangundangan yang berlaku di Indonesia, maka sudah seharusnya orang tuanya maupun lingkungan sekitarnya memberikan perlindungan terhadap seorang anak agar terhindar dari tindakan kekerasan, baik berupa kekerasan fisik, psikis, ekonomi dan penelantaran. Akan tetapi, memperhatikan realita yang ada di Kabupaten Solok, bahwasanya tindakan kekerasan masih terjadi di tengah masyarakat. Lebih buruknya lagi tindakan kekerasan dilakukan oleh orang yang berada di sekitar anak tersebut, yang sudah semestinya memberikan perlindungan kepadanya.

Dari informasi dan data yang penulis peroleh melalui Sekretaris Nagari Koto Hilalang Kecamatan Kubung Kabupaten Solok, menyatakan bahwa terdapat 70 orang korban pada tahun 2018 yang mengalami kekerasan dalam rumah tangga. Anak korban kekerasan dalam rumah tangga ini merata ada disetiap jorong yang ada di Nagari Koto 
Hilalang Kecamatan Kubung Kabupaten Solok.

Kasus kekerasan terhadap anak dalam rumah tangga di Koto Hilalang hanya diselesaikan di Kantor Wali Nagari saja, kalau seandainya tidak selesai di kantor Wali Nagari, maka berlanjutlah ke kepolisian setempat. Hal ini membuktikan bahwa seorang anak rentan menjadi korban kekerasan dalam rumah tangga yang dilakukan oleh orang-orang yang berada dalam lingkungan keluarganya. Padahal hukum keluarga Islam, Kompilasi Hukum Islam, perundang-undangan dan hukum internasional sudah menjelaskan secara tegas dan jelas bahwa anak memiliki haknya yang harus dilindungi oleh keluarganya. Berdasarkan wawancara yang penulis lakukan bersama AS yang merupakan korban dari tindakan perceraian orang tuannya akibat kekerasan dalam rumah tangga. AS terpaksa harus berhenti sekolah karena ayahnya tidak memberikan nafkah dan pendidikan kepadanya. Sehingga ia harus menanggung biaya hidupnya seharihari karena perceraian tersebut. Ibu dari AS pun tidak membantu memberikan biaya hidup kepadanya, karena ibunya menyuruh untuk meminta biaya hidup pada ayahnya. Hingga AS akhirnya pergi merantau dan bekerja sebagai buruh tani, walaupun anak se-umurnya belum layak untuk bekerja (Wawancara Pribadi tanggal 25 Desember 2018).
Selain itu penulis juga mewawancarai Awaluddin yang merupakan Tokoh Masyarakat yang ada di Koto Hilalang. Beliau menyampaikan bahwa anak banyak yang mengalami kekerasan dalam rumah tangga di Koto Hilalang. Sepengetahuannya banyak anak-anak yang terlunta-lunta dan tidak menentu arah hidupnya karena tindakan kekerasan yang di alami anak tersebut. Padahal orang tua berkewajiban memberikan perlindungan kepada anaknya, bukan sebaliknya. Harus ada jalan keluar yang jelas untuk menyelesaiakan perihal tersebut. Kalau semua komponen saling mengerti dan memahami termasuk orang tua, maka kekerasan terhadap anak ini bisa diatasi. Akan tetapi, belum terlihat olehnya adanya upaya yang serius untuk mengatasi permasalahan tersebut (Wawancara Pribadi tanggal 25 Desember 2018).

Dari uraian di atas, terdapat permasalahan berkaitan dengan perlindungan anak korban kekerasan dalam rumah tangga di Nagari Koto Hilalang Kecamatan Kubung Kabupaten Solok, sehingga menarik penulis untuk mengadakan penelitian berkaitan dengan kasus tersebut dengan judul : "Perlindungan Anak Korban Kekerasan Dalam Rumah Tangga Perspektif Hukum Keluarga Islam di Nagari Koto Hilalang Kecamatan Kubung Kabupaten Solok" 


\section{METODE PENELITIAN}

Jenis penelitian yang dilakukan adalah penelitian lapangan (field research), karena Penulis langsung melakukan penelitian di Kabupaten Solok. Dari segi tujuannya, Penulis menggunakan metode deskriptif untuk memberikan gambaran secara sistematis, faktual dan akurat terhadap suatu populasi dan daerah tertentu, mengenai sifat-sifat, karakteristik atau faktor-faktor tertentu. Adapun pendekatan yang digunakan yaitu pendekatan penelitian kualitatif, karena Penulis bermaksud mendapatkan data yang mendalam, mengandung makna, dan pasti, serta berfungsi menetapkan fokus penelitian, analisis data, menafsirkan data dan membuat kesimpulan atas temuannya

\section{HASIL PENELITIAN DAN PEMBAHASAN}

Hak-hak anak korban kekerasan dalam rumah tangga di Nagari Koto Hilalang Kecamatan Kubung Kabupaten Solok

Kedudukan anak sebagai generasi muda yang akan meneruskan cita-cita luhur bangsa, calon-calon pemimpin bangsa di masa mendatang dan sebagai sumber harapan bagi generasi terdahulu, perlu mendapat kesempatan seluasluasnya untuk tumbuh dan berkembang dengan wajar baik secara rohani, jasmani dan sosial. perlindungan anak merupakan usaha dan kegiatan seluruh lapisan masyarakat dalam berbagai kedudukan dan peranan, yang menyadari betul pentingnya anak bagi nusa dan bangsa di kemudian hari. Jika mereka telah matang pertumbuhan fisik maupun mental dan sosialnya, maka tiba saatnya menggantikan generasi terdahulu.

Perlindungan anak adalah segala usaha yang dilakukan untuk menciptakan kondisi agar setiap anak dapat melaksanakan hak dan kewajibannya demi perkembangan dan pertumbuhan anak secara wajar baik fisik, mental, dan sosial. perlindungan anak merupakan perwujudan adanya keadilan dalam suatu masyarakat, dengan demikian perlindungan anak diusahakan dalam berbagai bidang kehidupan bernegara dan bermasyarakat. Kegiatan perlindungan anak membawa akibat hukum, baik dalam kaitannya dengan hukum tertulis maupun hukum tidak tertulis.

Perlindungan anak tidak boleh dilakukan secara berlebihan dan memperhatikan dampaknya terhadap lingkungan maupun diri anak itu sendiri, sehingga usaha perlindungan yang dilakukan tidak berakibat negatif. Perlindungan anak dilaksanakan secara rasional, bertanggung jawab, dan bermanfaat. Hal itu mencerminkan suatu usaha yang efektif dan efisien. Usaha 
perlindungan anak tidak boleh mengakibatkan matinya inisiatif, kreativitas, keterampilan dan hal-hal lain yang menyebabkan ketergantungan kepada orang lain dan berperilaku tak terkendali, sehingga anak tidak memilikki kemampuan dan kemauan menggunakan hak-haknya dan melaksanakan kewajibankewajibannya.

Hukum perlindungan anak sebagai hukum (tertulis maupun tidak tertulis) harus menjamin anak benarbenar dapat melaksanakan hak dan kewajibannya. Aspek hukum perlindungan anak harus lebih dipusatkan kepada hak-hak anak yang diatur hukum dan bukan mengenai kewajiban karena mengingat secara hukum (yuridis) anak belum dibebani kewajiban.

Ruang lingkup kajian mengenai perlindungan anak, secara garis besar dapat dibedakan dalam dua pengertian pokok bersifat:

1. Yuridis (baik dalam ruang lingkup hukum publik maupun hukum perdata)

2. Non Yuridis (bidang sosial, kesehatan, dan pendidikan).

Berdasarkan hasil Seminar Perlindungan Anak/ Remaja yang diadakan oleh Pra Yuwana pada tahun 2017, terdapat dua perumusan tentang perlindungan anak, yaitu:

1. Segala daya upaya yang dilakukan secara sadar oleh setiap orang maupun lembaga pemeritah dan swasta yang bertujuan mengusahakan pengamanan, penguasaan, dan pemenuhan kesejahteraan fisik, mental an sosial anak dan remaja yang sesuai dengan kepentingan dan hak asasinya.

2. Segala daya upaya bersama yang dilakukan dengan sadar oleh perorangan, keluarga, masyarakat, badan-badan pemerintah dan swasta untuk pengamanan, pengadaan, dan pemenuhan kesejahteraan rohaniah dan jasmaniah anak berusia $0-21$ tahun, tidak dan belum pernah menikah, sesuai dengan hak asasi dan kepentingannya agar dapat mengembangkan dirinya seoptimal mungkin.

Pasal 1 angka 2 Undang-Undang Nomor 35 Tahun 2014 tentang Perubahan Atas Undang-Undang Nomor 23 Tahun 2002 tentang Perlindungan Anak bahwa perlindungan anak adalah segala kegiatan untuk menjamin dan melindungi anak dan hak-haknya agar dapat hidup, tumbuh, berkembang, dan berpartipasi, secara optimal sesuai dengan harkat dan martabat kemanusiaan, serta mendapat perlindungan dari kekerasan dan diskriminasi.

Perlindungan anak dapat juga kita artikan sebagai segala upaya yang ditujukan untuk memimimalisir, mencegah, merehabilitasi, dan 
memberdayakan anak yang dan/atau penderitaanpsikis berat mengalami tindak perlakuan salah (kekerasan psikis) tercatat 6 anak, (child abused), eksploitasi dan kekerasan seksual berupa pelecehan penelantaran, agar dapat menjamin dan pemerkosaan tercatat 4 anak dan kelangsungan hidup dan tumbuh kekerasan berupa penelantaran kembang anak secara wajar, baik fisik, tercatat 50 anak.

mental dan sosialnya.

Di Nagari Koto Hilalang Kecamatan Kubung Kabupaten Solok ini, kasus-kasus yang seperti kekerasan dalam rumah tangga jarang terungkap atau melapor ke Kantor Sekretaris Wali Nagari, karena keluarga yang mengalami kasus kekerasan menganggap bahwa kekerasan terhadap anak sebagai aib yang memalukan jika diungkap, perempuan atau anak yang mengalami kekerasan takut melapor karena alasannya bisa diselesaikan dalam ruang lingkup keluarga (Wawancara dengan Sekretaris Wali Nagari Koto Hilalang).

Berdasarkan data kekerasan dalam rumah tangga terhadap anak di Nagari Koto Hilalang Kecamatan Kubung Kabupaten Solok tercatat 4 jenis kekerasan yang terjadi, diantaranya kekerasan yang melibatkan kontak langsung dan dimaksudkan untuk menimbulkan perasaan intimidasi, cedera, atau penderitaan fisik lain atau kerusakan tubuh (kekerasan fisik) tercatat 10 anak, perbuatan yang mengakibatkan ketakutan, hilangnya rasa percaya diri, hilangnya kemampuan untuk bertindak, rasa tidak berdaya, tergolong tabu dan disadari melanggar batas-batas etika, ditengarai kasuskasus kekerasan kebanyakan jarang terekspos ke luar dan kalaupun kemudian diketahui umumnya biasanya berkat peran tetangga dan keterlibatan media massa atau karena ada kejadian yang menghebohkan. Seorang ayah atau ibu yang memukul anaknya atau bahkan menghajar dengan keras sekalipun, sepanjang apa yang mereka lakukan tidak sampai menimbulkan luka fisik yang serius atau mematikan, maka kejadian itu lewat dan menguap saja.

Pada saat itu, Saya mendengar seorang anak tetangga yang menangis dan berteriak karena kesakitan, ternyata anak itu habis berkelahi dengan kawannya. Padahal sebelumnya tangan anak itu sudah memar gara-gara berkelahi, kemudian anak itu melapor sama orang tuanya, akan tetapi bukan pertolongan yang didapat justru tambah kesakitan yang dia dapat, gara-gara berkelahi dengan temannya (Wawancara dengan Bundo Kanduang Nagari Koto Hilalang).

Padahal maksud dan tujuan melakukan tindakan yang tidak berprikemanusiaan itu adalah untuk 
membuat anak jerah atas kelakuannya, akan tetapi tindakan yang dilakukan itu adalah tindakan yang membuat anak celaka dan membuat jiwa anak terganggu. Yang jelas bahwa dampak yang ditimbulkan oleh tindak kekerasan orang tua terhadap anak lebih berdampak negatif baik dari aspek perkembangan fisik maupun dari aspek perkembangan kejiwaan atau psikis anak. Ringkasnya bahwa tindak kekerasan yang dijadikan landasan membina oleh orang tua terhadap anaknya hanya akan mendatangkan dampak atau efek negatif bagi perkembangan jiwa anak dalam kehidupan selanjutnya.

Kasus-kasus kekerasaan

terhadap anak biasanya berkaitan erat dengan pandangan dan pemahaman mengenai anak dan hak-haknya serta ketidakberdayaan dan ketergantungan anak pada orang tuanya. Karena dianggap belum dewasa, seorang anak dianggap belum bisa menentukan arah hidupnya sehingga segala sesuatunya harus dalam bimbingan orang tuanya, meskipun hal tersebut bertentangan dengan kehendak anak. Anak juga sering dianggap sebagai hak milik, sehingga apapun yang akan ditentukan atau dilakukan oleh orang tua terhadap anak tersebut adalah hak mutlak orang tuanya.

Orang tua berhak mendidik anak-anaknya sesuai dengan ajarannya masing-masing tergantung bagaimana cara orang tua mendidiknya. Namun terkadang orang tua menyalahgunakan wewenangnya dalam mendidik anakanaknya. Salah satu contoh adalah ketika orang tua memukul anaknya sebagai bentuk pembelajaran, namun terkadang cara mendidiknya itu berlebihan sampai terkadang tanpa disadari anak mengeluh dengan apa yang dialaminya. Tetapi seorang anak yang tidak mampu melawan dan mengharuskan hormat kepada orang tuanya.

“Keluarga saya merupakan keluarga tidak harmonis (Broken Home), karena di dalam keluarga sering terjadi tindak kekerasan, seperti ayah sering memukul ibu, dengan melihat dan menyaksikan kejadian tersebut saya takut pulang kerumah dan keluyuran di luar karena saya takut dipukul" (Wawancara dengan $\mathrm{AL})$.

Selain itu, sering pula terjadi dalam kehidupan rumah tangga adanya anak-anak yang tidak betah tinggal di rumah, disebabkan kelakuan orang tuanya yang tidak menjamin hak hidupnya serta tidak adanya rasa kasih sayang.

"Saya pergi meninggalkan rumah dan memilih hidup di rumah keluarga, karena di rumah tidak mendapatkan kasih sayang dari orang tua, hanya kekerasan, tekanan dan penyiksaan setiap hari yang saya dapatkan" (Wawancara dengan HT). 
Ungkapan di atas disadari atau tidak, penyebab utama kenakalan anak remaja adalah hubungan kedua orang tuanya yang tidak harmonis. Mereka menjadi tidak betah tinggal dirumah. Mereka lebih memilih hidup di jalanan atau dari keributan rumah yang menurutnya, tidak bisa memberi ketenangan. Tempat pelarian mereka adalah jalanan, sehinggga ia harus bergaul dengan teman-teman yang berkepribadian keras (Nabil Mahmud, 2010: 179).

Pergaulan

tersebut, kepribadiannya mulai terbentuk, ditambah dengan pengaruh lingkungan yang keras, akhirnya ia terjerumus ke dalam jurang kriminalitas. Dapat juga mengakibatkan anak menjadi trauma, sehingga dalam bertindak seorang anak akan lebih hati-hati dan berpikir panjang dalam melakukannya.

Kalau kekerasan ini disaksikan setiap hari besar kemungkinan dia menjadi traumatis, cenderung pendiam, sering marah hingga menangis. Dan lama kelamaan sifatnya menjadi general, artinya bukan hanya melihat teriakan atau pukulan orang tuanya saja, tetapi juga saat ia melihat hal itu dilakukan orang lain. Bahkan bukan tidak mungkin ia akan marah dengan orang lain yang belum tentu ada hubungannya dengan dia. Selain si anak menjadi traumatis kemungkinan besar juga si anak akan meniru perilaku orang tuanya untuk menyelesaikan suatu masalah jika dia sudah berkeluarga. Hal ini terjadi karena anak memperoleh model dalam cara menyelesaikan masalah. Misalnya ia melihat orang tuanya bertengkar dan kemudian melihat salah satu orang tuanya menggunakan kekerasan, pengalaman tersebut akan selalu membekas dalam dirinya, dan menjadi salah satu referensinya saat menyelesaikan masalah. Berdasarkan situasi tersebut fenomena KDRT dapat menular kepada orang lain sehingga KDRT tidak akan pernah menghilang di lingkungan keluarga atau akan selalu mengancam tiap-tiap keluarga.

"Saya sering berkelahi disaat teman mengejek, baik disekolah maupun diluar sekolah. Karena kalau tidak diajak berkelahi ia mengejek saya terus" (Wawancara dengan KH).

$$
\text { Perilaku di atas }
$$
menggambarkan seorang anak yang meniru perbuatan orang tuanya. Apabila ada masalah harus diselesaikan dengan kekerasan. Orang tua kadang tidak mengerti batas-batas kekerasan yang dilakukan terhadap anaknya yang bisa ditolerir. Bagaimanapun juga, usia anak adalah usia imitasi yang sangat dominan. Dengan perlakuan orang tua yang salah, dia akan mengidentifikasikan dirinya sesuai dengan objek imitasi yang dilihatnya.

Dampak lain yang dialami seorang anak adalah trauma. Karena anak yang menyaksikan pertengkaran 
dan penyiksaan yang dialami ibunya karena kekerasan tersebut, sangat berdampak pada psikis, mental bahkan kognitif anak. Mereka cenderung akan meniru tindakan tersebut, dan sangat disayangkan anak yang melihat ibunya mengalami kekerasan, akan mengalami gangguan perkembangan intelektualnya karena anak tersebut tidak bisa berkonsentrasi disekolahnya. Bahkan minat belajarnya berkurang karena trauma mengingat keadaan keluarganya.

Seharusnya saya sudah masuk Sekolah Tingkat Pertama (SMP), karena malas akhirnya prestasi menurun, saya tertinggal kelas oleh teman-teman. Padahal sebelumnya selalu dapat peringkat di kelas, akan tetapi prestasi itu hilang semenjak orang tua selalu bertengkar (Wawancara dengan SW). Lain halnya yang dialami MA, yang mengatakan bahwa: saya malas kesekolah, karena ketika berada di sekolah konsentrasi saya terganggu, akibat teringat oleh bayangan yang terjadi di rumah (Wawancara dengan MA).

$$
\text { Pada waktu penulis }
$$

mewawancarai HL anak korban kekerasan dalam rumah tangga yang sekarang duduk di bangku sekolah dasar, beliau mendapatkan kekerasan berupa penelantaran oleh orang tuanya yang sudah tidak hidup bersama lagi. Ibu HL tinggal di solok dan ayahnya bertempat tinggal di Pasaman, sedangkan HL tinggal bersama neneknya. Kalau ada uang HL selalu dikasih oleh Ibunya sedangkan ayahnya tidak lagi memberikan uang. Sedangkan sekarang Ibunya tidak lagi mengirim uang untuk HL. Untuk biaya hidupnya sehari-hari HL diberi uang dan makanan dari nenek serta mamaknya (Wawancara dengan HL).

Berdasarkan uraian di atas terlihat bahwa dampak dari kekerasan terhadap anak begitu mengenaskan. Mungkin belum banyak orang yang menyadari bahwa pemukulan yang bersifat fisik ataupun bentuk kekerasan lainnya itu bisa menyebabkan kerusakan emosial anak. Pasal 1 angka 2 Undang-Undang Nomor 35 Tahun 2014 tentang Perubahan Atas Undang-Undang Nomor 23 Tahun 2002 tentang Perlindungan Anak bahwa perlindungan anak adalah segala kegiatan untuk menjamin dan melindungi anak dan hak-haknya agar dapat hidup, tumbuh, berkembang, dan berpartipasi, secara optimal sesuai dengan harkat dan martabat kemanusiaan, serta mendapat perlindungan dari kekerasan dan diskriminasi

Perspektif hukum keluarga Islam terhadap hak-hak anak korban kekerasan dalam rumah tangga di Nagari Koto Hilalang Kecamatan Kubung Kabupaten Solok 
Anak, sesuai dengan kodratnya, adalah manusia yang memiliki banyak kelemahan dan keterbatasan, baik secara fisik, mental, maupun intelektual. Konsekwensi dari kenyataan tersebut, ia belum mampu memperjuangkan kepentingannya dan melindungi dirinya secara baik. Hal ini sering menjadi faktor penyebab terjadinya berbagai pelanggaran hakhak anak yang merugikan atau bahkan membahayakan kehidupan anak. Oleh sebab itu, berbagai peraturan dan mekanisme dibuat untuk memberikan perlindungan kepada anak agar terhindar dari berbagai pelanggaran hak. Nabi SAW menyadari benar keadaan anak yang lemah dan rentan mengalami pelanggaran hak tersebut. Oleh sebab itu, berbagai upaya dan kebijakan beliau lakukan untuk memberikan perlindungan maksimal kepada anak dan hak-hak mereka. Sepanjang pengamatan terhadap hadis-hadis yang berkaitan dengan masalah ini, terdapat beberapa kebijakan dan upaya yang dilakukan Nabi SAW sebagai berikut:

1. Larangan Pelanggaran Hak Anak

Bentuk perlindungan pertama yang diberikan di dalam hadishadis Nabi SAW, dalam aspek min jânib al-’adam, adalah adanya ketentuan-ketentuan hukum yang melarang segala perbuatan yang dapat merugikan dan melanggar hak-hak anak. Hal ini banyak sekali ditemukan di dalam hadis-hadis Rasulullah SAW. Dalam tataran umum, Nabi SAW melarang orang tua melakukan kejahatan atau kekerasan terhadap anak-anaknya, begitu pula sebaliknya. Larangan melakukan kejahatan ini mencakup segala bentuk perbuatan yang melanggar hak-hak anak. Sebagaimana sabda Nabi SAW.

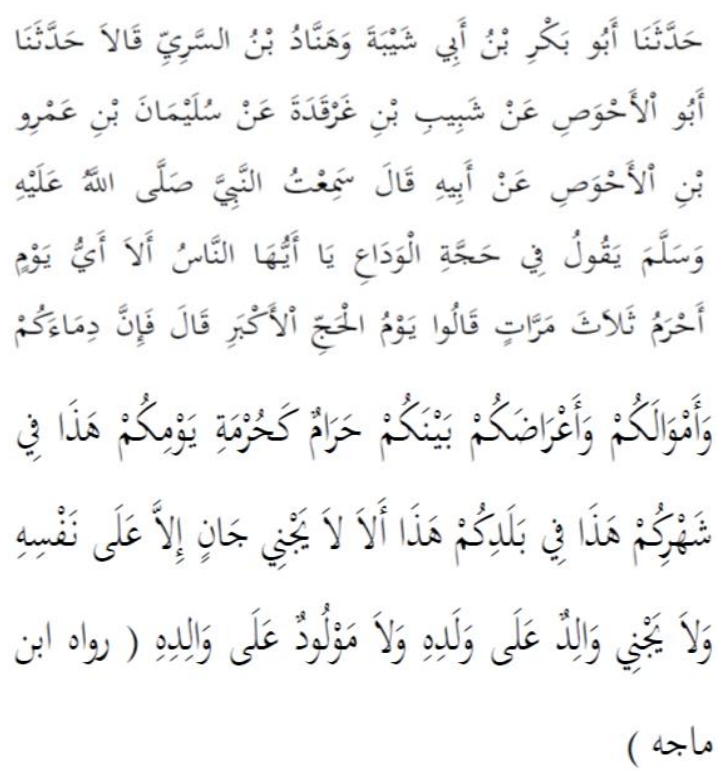

Hadits dari Abu Bakar bin Abi Syaibah dan Hannâd bin al-Sirri, dari alAhwash, dari Syabib bin Gharqadah, dari Sulaiman bin 'Amr bin al-Ahwash, dari ayahnya yang mendengar Nabi SAW bersabda ketika haji Wada: "Hai sekalian manusia. Ingatlah, hari manakah yang lebih suci?" Orang banyak menjawab: "Hari Haji Akbar." Nabi SAW bersabda: "Sesungguhnya darahmu, hartamu, dan kekayaanmu adalah suci di antara kamu sebagaimana 
sucinya harimu ini, pada bulanmu ini, di negerimu ini. Ingatlah, tidaklah sekali-kali seseorang melakukan tindak kejahatan melainkan akibatnya akan menimpa dirinya sendiri. Orang tua tidak boleh berbuat jahat kepada anaknya dan seorang anak tidak boleh berbuat jahat kepada orang tuanya." (H.R. Ibnu Majah).

\section{Tindakan jahat yang} dimaksud oleh hadis di atas dapat disamakan dengan tindakan kekerasan terhadap anak (child abuse) sebagaimana yang populer dibicarakan para ahli dewasa ini. Terry E. Lawson, seorang psikiater anak, menyebut empat macam child abuse, yakni emotional abuse (kekerasan emosional), verbal abuse (kekerasan wicara), physical abuse (kekerasan fisik) dan sexual abuse (kekerasan seksual). Emotional abuse dapat terjadi dalam bentuk pengabaian ketika anak meminta perhatian atau mengabaikan anak ketika mereka ingin dipeluk atau dilindungi. Verbal abuse dapat terjadi ketika orang tua membentak anak atau melontarkan kata-kata kasar kepada mereka. Physical abuse dapat meliputi tindakan memukul anak, baik dengan tangan ataupun menggunakan alat, termasuk juga pembunuhan. Sedangkan sexual abuse adalah tindakan yang melecehkan anak secara seksual. Termasuk dalam tindak kekerasan ini adalah kekerasan ekonomi, seperti penelantaran hak nafkah anak, hak waris anak, dan mempekerjakan anak dengan paksa untuk memenuhi kebutuhan finansial keluarga.

\section{Sanksi Hukum dan Moral}

Perlindungan terhadap hakhak anak tidak cukup hanya dengan membuat ketentuan hukum yang melarang perbuatan melanggar hak-hak anak. Dalam kenyataannya, meskipun berbagai peraturan telah dibuat untuk melindungi hak-hak anak, namun pelanggaran hak anak tetap berlangsung. Oleh sebab itu, di samping pembuatan aturan hukum, diperlukan juga sanksi hukum untuk memperkuat aturan hukum dan untuk menekan angka pelanggaran hak-hak anak.

Di dalam Islam, sangsi hukum merupakan wilayah hukum pidana Islam. Hukum Pidana Islam memang menyiapkan sanksi hukum bagi pelaku tindak pidana agar ia tidak melanjutkan perbuatan pidananya sekaligus memberikan efek rasa takut kepada orang lain agar tidak melakukan tindak pidana yang sama. Dengan demikian, tujuan syariat Islam untuk menjamin dan memelihara kemaslahatan kelima pilar pokok kehidupan manusia, yakni pemeliharaan hak agama, jiwa, akal, keturunan, dan harta, dapat tercapai dengan baik. 
Nabi SAW, juga menyiapkan sanksi hukum bagi pelaku pelanggar hak anak di samping memberikan aturan yang melarang pelanggaran hak-hak anak sebagaimana telah dipaparkan di atas, agar aturan hukum yang telah dibentuk dapat ditaati dan hak-hak anak lebih terlindungi. Di antara ketentuan sanksi pidana yang ditetapkan oleh Nabi SAW terkait pelanggaran hak anak adalah sanksi hukum terhadap terhadap pembunuhan janin, sebagai bentuk perlindungan atas hak hidup anak. Nabi SAW bersabda:

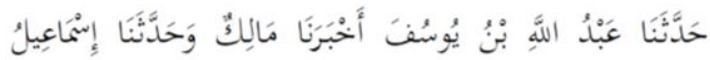

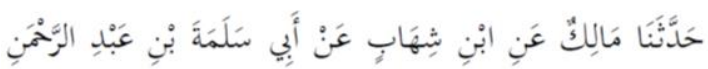

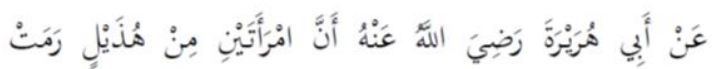

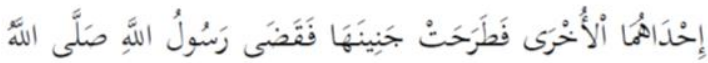

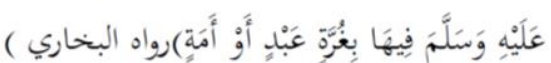
Hadis dari 'Abillah bin Yusuf, dari Malik, dari Isma'il, dari Malik, dari Ibnu Syihab, dari Abi Salamah bin 'Abdirrahman, dari Abu Hurairah r.a. bahwa dua orang wanita dari Bani Huzail bertengkar, salah satunya melempar yang lain dan menyebabkan gugur janinnya. Maka Rasulullah SAW menetapkan hukuman denda berupa budak laki-laki atau budak perempuan." (H.R. al-Bukhari).

Hadis tersebut menjelaskan bahwa Nabi SAW memberikan sanksi hukum terhadap pembunuhan janin, berbentuk pembayaran denda berupa budak laki-laki atau budak perempuan. Hadis Nabi SAW tersebut tidak menjelaskan pada umur berapa janin tersebut gugur akibat perbuatan pidana. Dengan demikian dapat diartikan bahwa janin dalam usia berapapun berhak mendapat perlindungan hukum sehingga orang yang menggugurkannya, atau yang menyebabkan kegugurannya, baik sengaja atau tidak disengaja, diberikan sanksi hukum pidana berupa denda (ghurrah).

Dalam kitabnya al-Mughny, Ibn Qudamah menjelaskan bahwa ghurrah (denda) tersebut menjadi hak janin yang diberikan kepada ahli warisnya. Hukuman yang sama diberikan kepada ibu yang menggugurkan kandungannya (aborsi) dan pihak yang terlibat dalam pelaksanaan pengguguran kandungan.

Berdasarkan hal uraian tersebut, terlihat jelas bahwa kekerasan terhadap anak dalam rumah tangga merupakan perbuatan yang dilarang. Orang tua harus memberikan pendidikan dan kebutuhan yang baik untuk anak-anaknya, sehingga anakanaknya terjamin kehidupannya dan masa depannya di masa yang akan datang.

\section{PENUTUP}

\section{Kesimpulan}

Hak-hak anak korban kekerasan dalam rumah tangga belum mendapatkan haknya secara maksimal, seperti hak untuk memperoleh perlindungan, pendidikan dan nafkah dari orang 
tuanya. Hal ini disebabkan oleh beberapa faktor diantaranya kondisi orang tua, faktor pendidikan atau pengetahuan, faktor anak dan faktor ekonomi. Dampak yang ditimbulkan oleh tindak kekerasan orang tua terhadap anak lebih berdampak negatif baik dari aspek perkembangan fisik maupun dari aspek perkembangan kejiwaan atau pisikis anak. Bahwa tindak kekerasan yang dijadikan landasan membina oleh orangtua terhadap anaknya hanya akan mendatangkan dampak atau efek negatif bagi perkembangan jiwa anak dalam kahidupan selanjutnya. Dampaknya antara lain: rasa trauma, suka berkelahi, meninggalkan rumah, takut, psikologis terganggu, rasa sakit.

Menurut perspektif Hukum Keluarga Islam sebagaimana yang berlaku dalam hukum positif Indonesia dalam KHI Pasal 105 Ayat (3) yaitu menjadi orang yang bertanggung jawab dalam hal financial anak untuk memenuhi kebutuhannya Pernyataan dalam KHI ini juga dikuatkan dalam hukum positif di Indonesia dalam Pasal 41 ayat (1) dan (2) UU No. 1 Tahun 1974 tentang Perkawinan menyatakan bahwa bapak dan ibu tetap berkewajiban memelihara dan mendidik anakanaknya. Dalam hal ini sangat jelas apa yang dimandatkan dalam KHI dan UU Perkawinan disini adalah memelihara dan mendidik anak adalah kewajiban kedua orang tua untuk memenuhinya. Dengan kata lain antara Undangundang No. 1 Tahun 1974 tentang
Perkawinan dan Kompilasi Hukum Islam tidak ada petentangan mengenai hak anak, keduanya saling menguatkan. Nabi Muhammad Saw di dalam hadis-hadis berupaya keras mencegah dan melarang segala sesuatu yang dapat mengurangi, membahayakan, dan menghapuskan hak-hak anak. Dalam konteks ini, Nabi Muhammad Saw membuat ketentuan hukum yang melarang segala perbuatan yang melanggar hak-hak anak, seperti tindak kekerasan terhadap anak (child abuse), baik dalam bentuk kekerasan emosional (emotional abuse), kekerasan wicara (verbal abuse), kekerasan fisik (physical abuse), kekerasan seksual (sexual abuse), dan sebagainya. Pada perlindungan bentuk kedua ini, hukum pidana Islam memiliki peranan penting. Berbagai aturan hukum tentang perlindungan anak memerlukan sangsi hukum agar lebih dipatuhi dan lebih dapat melindungi hak-hak anak dengan lebih baik. Di samping pemberian sangsi pidana yang bersifat duniawi, Nabi Muhammad Saw juga memberikan ancaman sanksi moral, seperti dosa, siksa akhirat, dan pengharaman surga untuk memperkuat perlindungan terhadap hak-hak anak.

\section{Saran}

Perlindungan Anak Korban Kekerasan menjadi masalah yang dari dahulu menjadi bahan pembicaraan dalam kehidupan bermasyarkat yang merupakan bagian dari masalah 
rumah tangga. Dengan adanya penelitian ini diharapkan dapat memberikan kontribusi besar dalam upaya perlindungan anak dalam kehidupan berkeluarga di masyarakat.

\section{KEPUSTAKAAN ACUAN}

Abdul Wahid, 2001, Perlindungan Terhadap Korban Kekerasan Advokasi atas Hak Asasi Perempuan, Bandung: Refika Aditama

Abu Hanifah, Permasalahan Kekerasan Dalam Rumah Tangga dan Alternatif Pemecahannya, Jurnal Penelitian dan Pengembangan Kesejahteraan Sosial, Vol 12, No. 03, 2017

Abu Huraerah, 2010, Kekerasan Terhadap Anak, Bandung: Nuansa Cendekia

Adil Samadani, 2013, Kompetensi Pengadilan Agama Terhadap Tindak Kekerasan dalam Rumah Tangga, Yogyakarta: Graha Ilmu

Allamah Kamal Faqih Imani, 2003, Tafsir Nurul Quran terj. Hikmat Danaatmaja, Jakarta: Al-Huda, jil. 2

Aulia Muthiah, 2017, Hukum IslamDinamika Perkembangan Seputar Hukum Perkawinan dan Hukum Kewarisan, Yogyakarta: Pustaka Baru Press

Bagong Suyanto, 2003, Pelanggaran Hak dan Perlindungan Sosial Bagi Anak Rawan, Surabaya: Airlangga University Press

Elimartati, 2013, Bunga Rampai Perkawinan di Indonesia,
Batusangkar:

STAIN

Batusangkar Press

Faqihuddin Abdul Kodir, Berbakti pada Orang Tua; Antara Hak dan Kewajiban, (online),(www.fahmina.org, diakses 23 juli 2008).

Femmy Silaswaty Faried, Optimalisasi Perlindungan Anak Melalui Penetapan Hukuman Kebiri, Jurnal Serambi Hukum Vol. 11 No. 01 Februari - Juli 2017

Imam Suprayogo dan Tobroni, 2001, Metodologi Penelitian SosialAgama, Bandung : Remaja

Imran Siswandi, Perlindungan Anak dalam Perspektif Hukum Islam dan HAM, Jurnal Al-Mawarid, Vol. XI, No. 2, Sept-Jan 2011

Jamaal 'Abdurrahman, 2005, Kaifa Rabbahumun Nabiyyul Amiin, terj. Bahrun Abu Bakar, Tahapan Mendidik Anak Teladan Rasulullah, Bandung: Irsyad Baitus Salam

Juraidi, 2013, Jerat Perbudakan Masa Kini, Jakarta: Bina Purna Pariwara

Kompilasi Hukum Islam

Undang-undang Nomor 1 Tahun 1974 tentang Perkawinan

Undang-Undang Nomor 35 Tahun 2014 tentang Perubahan Atas Undang-Undang Nomor 23 Tahun 2002 tentang Perlindungan Anak bahwa perlindungan anak

Yusuf Qardhawi, 1995, Fatwa-Fatwa Kontemporer, Jakarta: Gema Insani Press

Zainuddin Ali, 2007, Hukum Pidana Islam, Jakarta : Sinar Grafika 